\title{
Main causes of cattle slaughter condemnation under the state sanitary inspection in Bahia, Brazil
}

\section{Principais causas de condenação de bovinos abatidos sob inspeção sanitária estadual na Bahia, Brasil}

\author{
Juliana Sant'Ana Falcão Leite'; Rafael Sepúlveda Fonsêca Trevisan Passos²; \\ Thiago da Matta Pires Cruz; Brenno Guimarães Barreto ${ }^{\text {; }}$ Maurício Costa \\ Alves da Silva ${ }^{3}$; Carlos Pasqualin Cavalheiro ${ }^{3 *}$
}

\section{Highlights}

The main causes of condemnation were not related to zoonosis.

The main causes involved local condemnation of organs.

Nephritis was the main cause of condemnation.

High rates of non-pathological causes, such as blood aspiration were also observed.

Feira de Santana region was responsible for most of the condemnations.

\begin{abstract}
Slaughter condemnations are important sources of information on cattle health and handling. The aim of this study was to evaluate the main causes of condemnation of cattle slaughter under the state sanitary inspection by the Diretoria de Inspeção de Produtos de Origem Agropecuária (DIPA) of Agência de Defesa Agropecuária da Bahia (ADAB), in Bahia, Brazil. A retrospective data of all cattle slaughtered from 2012 to 2019 was obtained from DIPA - ADAB. During this period, 4,635,615 cattle were slaughtered and 1,452,472 (31.33\%) condemnations were registered to have occurred at varying levels in all regions of the state. The more condemned organs were kidneys and lungs; and the main causes of condemnation were nephritis (11.79\%), congestion (11.20\%), emphysema (10.72\%), blood aspiration (8.36\%), renal cysts $(5.75 \%)$, and abscesses (5.71\%). However, other condemnation causes such as cysticercosis, fasciolosis, and tuberculosis were observed at lower rates. Results showed that the main causes of condemnation of cattle slaughter were not related to zoonotic diseases instead were more involved in partial condemnation of organs.
\end{abstract}

Key words: Congestion. Economic loss. Emphysema. Meat inspection. Nephritis.

1 Undergraduate Students, Veterinary Medicine, Universidade Federal da Bahia, Escola de Medicina Veterinária e Zootecnia, Laboratório de Inspeção e Tecnologia de Carnes e Derivados, UFBA / EMEVZ / LabCarne, Salvador, BA, Brazil. E-mail: julianaleite7@outlook.com; thiago.cruz95@hotmail.com; bgbarreto@outlook.com

2 Student of the Doctoral Course of Food Science, UFBA / LabCarne, Salvador, BA, Brazil. E-mail: rafael.sepulveda@ ufba.br

3 Profs. Drs., Department of Preventive Veterinary Medicine and Animal Production, UFBA / EMEVZ / LabCarne, Salvador, BA, Brazil. E-mail: mcasilva@ufba.br; carlos.cavalheiro@ufba.br

* Author for correspondence

Received: June 28, 2021 - Approved: Oct. 20, 2021 


\section{Resumo}

As condenações no momento do abate dos animais são importantes fontes de informação sobre a saúde e o manejo do rebanho. Por isso, o objetivo deste estudo foi avaliar as principais causas de condenações em bovinos abatidos sob sistema de inspeção estadual da Diretoria de Inspeção de Produtos de Origem Animal (DIPA) da Agência de Defesa Agropecuária da Bahia (ADAB), no estado da Bahia, Brasil. O estudo retrospectivo obteve os dados da DIPA - ADAB e analisou os dados de animais abatidos entre 2012 e 2019. Nesse período, foram abatidos 4.635 .615 bovinos e 1.452.472 (31,33\%) de condenações foram observadas em todas as regiões variando em diferentes níveis. Os órgãos mais condenados foram rins e pulmões e as principais causas de condenação encontradas foram nefrite $(11,79 \%)$, congestão $(11,20 \%)$, enfisema $(10,72 \%)$, aspiração de sangue $(8,36 \%)$, cistos renais $(5,75 \%)$ e abscessos $(5,71 \%)$. No entanto, outras causas com taxas de condenação menores como cisticercose, fasciolose e tuberculose também foram observadas. Os resultados mostram que as principais causas de condenação não estão relacionadas com doenças com potencial zoonótico e levam a condenações parciais das vísceras acometidas.

Palavras-chave: Congestão. Enfisema. Inspeção de carnes. Nefrite. Perdas econômicas.

\section{Introduction}

Brazil has one of the largest bovine farms globally. In 2020, the country had a herd of 217 million heads and official data shows that Bahia state has the $10^{\text {th }}$ largest cattle herd in Brazil with approximately 8.2 million animals distributed across 417 municipalities. In addition, Bahia state was responsible for $3.7 \%$ of those 32.4 million cattle slaughtered in Brazil in 2019 (Instituto Brasileiro de Geografia e Estatística [IBGE], 2021).

Slaughterhouses prevent the public from consuming poor-quality meat or meat that may be infected with zoonotic diseases. The final quality and safety of the meat depends on the official inspection system at the federal, state, and municipal levels. The guidelines of Brazilian sanitary inspection are mentioned in the Regulamento da Inspeção Industrial e Sanitária de Produtos de Origem Animal (RIISPOA) (Decreto $n^{\circ}$. 9.013, 2017). The administration of the official sanitary inspection service in Brazilian slaughterhouses is regulated by Federal Law No. 7.889 instituted in 1989, which makes the Ministério da Agricultura, Pecuária e Abastecimento (MAPA) responsible for regulation and inspection of establishments engaged in interstate or international commerce. The state secretariats of agriculture, federal districts, and territories regulate the establishments carrying out intermunicipal trade. Finally, products of animal origin that are subjected to municipal sanitation can only be marketed locally (Bica, Copetti, \& Brum, 2018).

Slaughtered animals are subjected to both ante-mortem and post-mortem inspection procedures according to the RIISPOA guidelines (Decreto $n^{\circ} .9 .013,2017$ ). All livestock presented for slaughter must undergo ante-mortem inspection, which involves observing animals at rest and in motion. During post-mortem inspection, carcass, carcass parts, cavities, organs, tissues, and lymph nodes are examined by palpation and incisions to find lesions (Decreto $\mathrm{n}^{\circ}$. 9.013, 2017). During both procedures, 
lesions promoted by biological agents especially with zoonotic potential that may be hazardous to public health and injuries caused due to improper handling, including animal welfare problems, result in direct and indirect losses due to condemnations.

In Brazil, most of the slaughterhouse condemnations are due to parasitic lesions, such as hydatidosis, cysticercosis, and fasciolosis [4], which are also the reason for most condemnations in other developing countries such as Sudan, Iran, and Ethiopia (Molla, Nazir, Mohammed, \& Tintagu, 2020; Kheder \& Mohamed, 2021; Khedri et al., 2021). However, different causes of carcass and organ condemnation can show higher condemnation rates depending on the region of the country, the sanitary inspection and the technology used for animal husbandry and handling. Cysticercosis, hydatidosis, and tuberculosis are the important causes of condemnation of cattle slaughter in the states Rio Grande do Sul (Bica et al., 2018; Bem Bidone et al., 2021) and Minas Gerais (Oliveira et al., 2020). According to Silva, Groff, Bassani and Pianho (2016), cachexia was responsible for $24.74 \%$ of the total carcass condemnations in one slaughterhouse in Paraná, Brazil. Emphysema was the main cause of condemnation in Garanhuns micro-region (Pernambuco, Brazil) (Almeida, Silva, Torres, \& Franque, 2017). In Goias state, abscesses and bruises were the main causes of condemnation (Lima et al., 2019).

However, no studies have been conducted to compile the information and interpretation data of the main causes of carcass and organ condemnation in the state of Bahia, Brazil. The aim of this study was to evaluate, retrospectively, the main causes of carcass and organ condemnation during the post-mortem inspection of carcasses of cattle slaughtered under state sanitary inspection in the state of Bahia between 2012 and 2019.

\section{Materials and Methods}

$$
\text { An eight-year }
$$

(2012-2019)

retrospective study was conducted to collect data on slaughtered cattle and causes of total and partial carcass and/or organ condemnations from slaughterhouses in Bahia, subject to the state sanitary inspection. Information for the same was obtained from the DIPA. Each carcass and organ were thoroughly examined through inspection, palpation, and incision, following the regulations set by the state inspection service of Bahia under the Law No. 12,215 and Decree No. 15,004, which were based on RIISPOA revoked in 2017 by Decree No. 9,013 (Decreto no. 9.013, 2017). Official veterinarians recorded information on condemnation rates on standard DIPA forms at the time of slaughtering. In the obtained data, lesion locations and their results (partial or total condemnation) were not specified. Data was compiled in 14 administrative regions defined by the DIPA, encompassing 417 municipalities. Data was tabulated in Microsoft Excel (Microsoft Office ${ }^{\circledR}$ ) and analyzed in a descriptive way using relative and absolute frequencies of condemnation. Causes of condemnation of cattle slaughter under state sanitary inspection were considered relevant when rates greater than $10 \%$ were observed in at least one of the years analyzed.

\section{Results and Discussion}

Data on the number of cattle slaughtered and condemnations over the 
eight years (2012-19) are displayed as numbers and percentages in Table 1. A total of $4,635,615$ cattle were slaughtered in Bahia, between 2012 and 2019, under the state sanitary inspection. In the same period, $3,306,871$ cattle were slaughtered in Bahia under the federal sanitary inspection (Sistema de Informações Gerenciais do Serviço de Inspeção Federal [SIGSIF], 2021).

The regions of Feira de Santana (22.37\%), Ribeira do Pombal (19.86\%), Vitória da Conquista (15.66\%), and Simões Filho (15.64\%) accounted for $73.53 \%$ of cattle slaughtered under state sanitary inspection. These regions are characterized by a high population density and consequently, high demand formeat. Other regions withlower rates of cattle slaughtered are Barreiras (8.11\%), Itabuna (6.50\%), Miguel Calmon (2.97\%), Santa
Maria da Vitória (2.75\%), Guanambi (2.24\%), Juazeiro (1.56\%), Teixeira de Freitas (1.28\%), Itaberaba (0.80\%), Paulo Afonso (0.24\%), and Jequié $(0.03 \%)$. In the same period, a total of 1,452,472 condemnations were done, representing $31.33 \%$ of the total slaughtered animals (Table 1 ). In addition, it was observed that the number of slaughtered animals increased over the years, with 2017 having the highest number. Conversely, the rates of condemnation decreased from $62.58 \%$ in 2013 to $9.04 \%$ in 2017. Better conditions of cattle husbandry associated with investment in health and animal welfare procedures and training of slaughterhouse workers might be responsible for this decrease in condemnation rates. Livestock is an important economy sector of Bahia. Lower rates of condemnation of cattle slaughter imply lower economic loss.

\section{Table 1}

Average rates of cattle slaughtered under state sanitary inspection in the state of Bahia, Brazil and condemnations found between 2012 and 2019

\begin{tabular}{|cccc|}
\hline Year & Slaughtered animals & Condemnations & $\%$ \\
\hline 2012 & 469,181 & 235,076 & 50.10 \\
\hline 2013 & 598,231 & 374,359 & 62.58 \\
\hline 2014 & 597,063 & 331,746 & 55.57 \\
\hline 2015 & 500,787 & 208,770 & 41.69 \\
\hline 2016 & 578,668 & 87,019 & 15.04 \\
\hline 2017 & 672,007 & 60,762 & 9.04 \\
\hline 2018 & 658,175 & 81,692 & 12.41 \\
\hline 2019 & 561,503 & 73,048 & 13.00 \\
\hline Total & $4,635,615$ & $1,452,472$ & 31.33 \\
\hline
\end{tabular}


The retrospective study revealed that main causes of condemnation, especially affecting organs like kidney and lungs, are nephritis (171,313 condemnations; $11.79 \%)$, congestion (162,651; 11.20\%), emphysema $(155,637 ; 10.72 \%)$, blood aspiration $(121,441$; $8.36 \%)$, urinary cists $(83,544 ; 5.75 \%)$, and abscess $(82,986 ; 5.71 \%)$ that showed rates of condemnation higher than $10 \%$ in at least one of the years analyzed (Table 2). The results showed that the main causes of condemnation were not related to zoonotic diseases with considerable impact on public health, and were generally local lesions. This is probably due to the efforts made by the Brazilian authorities in controlling infectious diseases such as brucellosis and tuberculosis, which are being monitored since 2001 by the National Program for the Control and Eradication of Animal Brucellosis and Tuberculosis, and was recently revised by the normative instruction No. 10 dated 3rd March 2017. According to Ferreira et al. (2016), the program resulted in the initiation of a series of structuring actions, especially those involved in accreditation of veterinarians to perform diagnostic tests and official control of all batches of vaccines against brucellosis produced by private laboratories, and a large volume of high-quality epidemiological data was produced. All these improvements resulted in better sanitary conditions of the cattle and consequently in fewer condemnations due to these diseases. In addition, in a local context, $\mathrm{ADAB}$ has been conducting a surveillance program for monitoring tuberculosis in slaughterhouses under state sanitary system inspection since 2015, with the aim of eradicating the tuberculosis in Bahia (Agência Estadual de Defesa Agropecuária do Estado da Bahia [ADAB], 2015).

According to the data available at Sistema de Informações Gerenciais do Serviço de Inspeção Federal (SIGSIF), in cattle slaughtered during the period between 2012 and 2019 under the federal sanitary inspection, nephritis was responsible for 101,863 condemnations, congestion for 391,561, emphysema for 214,797, blood aspiration for 129,463, urinary cists for 85,639 , and abscess for 60,908 (SIGSIF, 2021). These results indicate that the main causes of condemnation of cattle slaughter under the state sanitary inspection also have a great impact on cattle slaughter under the federal sanitary inspection in Bahia.

The main causes of condemnation observed in the years analyzed affect the organs resulting in their total condemnation. Even organs of lower commercial value are an important protein source, especially for low-income population (Fruet et al., 2013). In addition, the organs may be part of meat product's formulation. High organ condemnation rates result in reduction of meat industry profitability. 
Table 2

Average rates of nephritis, congestion, and emphysema condemnation in cattle slaughtered between 2012 and 2019 in the state of Bahia, Brazil under the state sanitary inspection

\begin{tabular}{|c|c|c|c|c|c|c|c|c|c|c|c|c|}
\hline \multirow{3}{*}{ Year } & \multicolumn{12}{|c|}{ Condemnations } \\
\hline & \multicolumn{2}{|c|}{ Nephritis } & \multicolumn{2}{|c|}{ Congestion } & \multicolumn{2}{|c|}{ Emphysema } & \multicolumn{2}{|c|}{ Blood aspiration } & \multicolumn{2}{|c|}{ Renal cysts } & \multicolumn{2}{|c|}{ Abscess } \\
\hline & Total & $\%$ & Total & $\%$ & Total & $\%$ & Total & $\%$ & Total & $\%$ & Total & $\%$ \\
\hline 2012 & 29,401 & 12.51 & 28,805 & 12.25 & 29,257 & 12.45 & 25,025 & 10.65 & 11,717 & 4.98 & 11,091 & 4.72 \\
\hline 2013 & 49,921 & 13.34 & 40,625 & 10.85 & 39,613 & 10.58 & 33,211 & 8.87 & 19,531 & 5.22 & 15,884 & 4.24 \\
\hline 2014 & 36,117 & 10.89 & 32,728 & 9.87 & 37,580 & 11.33 & 30,163 & 9.09 & 15,454 & 4.66 & 13,903 & 4.19 \\
\hline 2015 & 27,730 & 13.28 & 22,978 & 11.01 & 22,693 & 10.87 & 14,378 & 6.89 & 14,165 & 6.78 & 12,878 & 6.17 \\
\hline 2016 & 8,825 & 10.14 & 9,461 & 10.87 & 8,027 & 9.22 & 5,844 & 6.72 & 9,158 & 10.52 & 5,759 & 6.62 \\
\hline 2017 & 5,428 & 8.93 & 7,951 & 13.09 & 4,923 & 8.10 & 3,993 & 6.57 & 4,626 & 7.61 & 6,931 & 11.41 \\
\hline 2018 & 7,529 & 9.22 & 10,287 & 12.59 & 7,250 & 8.87 & 4,317 & 5.28 & 4,678 & 5.73 & 8,941 & 10.94 \\
\hline 2019 & 6,362 & 8.71 & 9,816 & 13.44 & 6,294 & 8.62 & 4,510 & 6.17 & 4,215 & 5.77 & 7,599 & 10.40 \\
\hline Total & 171,313 & 11.79 & 162,651 & 11.20 & 155,637 & 10.72 & 121,441 & 8.36 & 83,544 & 5.75 & 82,986 & 5.71 \\
\hline
\end{tabular}

Nephritis (11.79\%) was the main cause of condemnation in cattle slaughtered under state sanitary inspection in Bahia from 2012 to 2019 (Table 2). Condemnation rates of nephritis fluctuated throughout the years, but were higher than $10 \%$ between 2012 and 2016. Nephritis is an inflammatory, degenerative kidney disease that is often referred to as "white spotted kidney". The lesion is characterized by irregular greyishwhite areas measuring up to $5 \mathrm{~mm}$, generally associated with infections by Lesptospira spp or other bacteria (Azizi, Kheirandish, \& Rahimi, 2014). This is a nonspecific lesion, and according to the RIISPOA, kidneys with nephritis should be completely condemned on post-mortem inspection and possible causes should be investigated (Decreto $n^{\circ}$. $9.013,2017)$. Mummed and Webb (2015) also reported nephritis as the reason for $10.94 \%$ of the kidney condemnations in Ethiopia.

The second main cause of condemnation in cattle between 2012 and 2019 in Bahia state was congestion (11.20\%)
(Table 2). The rates of condemnation for that lesion were quite similar throughout the years and were between 9.87\% (2014) and 13.44\% (2019). Congestion is characterized by blood accumulation in an organ and generally involves hepatic lesions associated with heart failure. Other organs can also be affected by congestion lesion, such as the kidneys. However, the obtained data does not stipulate the exact organs involved in the condemnation rates. Lung congestion was responsible for $10.90 \%$ of lung condemnations in Paraná state, Brazil [19]. On the contrary, liver congestion was responsible for 0.1 to $0.5 \%$ of condemnations in Sudan [6].

According to Table 2, emphysema was responsible for 155,637 (10.72\%) condemnations in cattle slaughtered under state sanitary inspection in Bahia between 2012 and 2019. The incidence of emphysema was higher in 2012 (12.45\%) and decreased over the years analyzed. The lowest rate of condemnation by emphysema was noted in 2017 (8.10\%) (Table 2). Pulmonary emphysema 
refers to an excessive abnormal permanent accumulation of air in the lungs. Historically, emphysema has been directly associated with acute bovine pulmonary emphysema which is caused by pneumotoxins from the forage.

Emphysema is also a secondary condition resulting from airflow obstruction in the lungs due to bronchopneumonia or agonic breathing on the moment of stunning (Almeida et al., 2017). Then, the reason of emphysema should be properly investigated between pathologic and failures during the slaughter process. Emphysema was also reported as the main cause of lung condemnation in cattle slaughtered in Ethiopia (18.93\%) (Mummed \& Webb, 2015), in Garanhuns, Pernambuco state (48.37\%) (Almeida et al., 2017), under federal sanitary inspection in Parana state (33\%) (Marino et al., 2016), and under municipal sanitary inspection in Santa Maria, Rio Grande do Sul state (11.96\%) (Fruet et al., 2013). However, according to (Fruet et al., 2013) due to low commercial value of lungs, condemnations do not result in high economic losses.

Blood aspiration was the cause of $8.36 \%$ of condemnation cases in cattle between 2012 and 2019 (Table 2). The rates of condemnation showed a declining trend over the years, with rates varying from $10.65 \%$ in 2012 to $5.28 \%$ in 2018 and $6.19 \%$ in 2019 (Table 2). Blood aspiration is an indicator of stress as the animal agonizes while trying to breathe after its neck has been cut. Furthermore, this lesion could occur due to failure in the bleedout process leading to injuries in trachea (Marino et al., 2016). This post-mortem lesion is associated with animal welfare problems and its reasons must be properly investigated. Probably, the trend of decline in blood aspiration rates of condemnation observed in this study (Table 2) was the consequence of training the slaughterhouse workers over the years. Higher rates of condemnation due to blood aspiration were reported by Marino et al. (2016) in slaughterhouses under federal sanitary inspection (34.60\%), while lower rates were found by Fruet et al. (2013) (10.05\%) and Dantas, Pimentel, Câmara, Batista and Dias (2015) (12.30\%) in slaughterhouses under municipal sanitary inspection.

Renal cysts were responsible for $5.75 \%$ of condemnations in cattle slaughtered under state sanitary inspection in Bahia. The rate of condemnation was higher in 2016 (10.52\%), while that of the remaining years analyzed were between 4.66 and $7.61 \%$ (Table 2). Renal cysts are round pouches of fluid that form on or in the kidneys and are associated with disorders that may impair kidney function. Renal cysts related to condemnation of slaughtered cattle during the period analyzed were properly differentiated from hydatid cysts during postmortem inspection. In general, presence of cysts are local lesions, but may led to total condemnation of kidneys (Decreto $n^{\circ}$. 9.013, 2017). However, low economic losses are observed because of low commercial value of the kidneys.

Finally, condemnation rate of $5.71 \%$ was found for abscess in cattle slaughtered under state sanitary inspection in Bahia between 2012 and 2019. According to Table 2 , a trend of increasing rates (higher than 10\%) were observed in 2017, 2018, and 2019 years. Abscess can be found in any part of the organ and/or carcasses. They are characterized by the accumulation of pus due to the presence of pyogenic bacteria and is most often because of secondary bacterial infection. In addition, abscesses may discharge the creamy pus leading to carcass and/or organs 
contamination. In this study, data available do not differentiate between abscesses found on carcass and in the organs. The values shown in Table 2 were related to the total abscesses found in the analyzed period (2012-2019).

According to Assis, RezendeLago, Marchi and D'Amato (2011), partial condemnation of carcasses due to abscesses caused by vaccinations and medications are the main causes of economic losses in packing plants in Brazil. The Brazilian law states that organs or carcasses exhibiting abscesses or suppurative lesions must be removed and only the affected organs and parts shall be condemned. In addition, carcass or parts thereof, which are accidentally contaminated with pus, shall also be condemned (Decreto $\mathrm{n}^{\circ}$. 9.013, 2017). According to Lima et al. (2019), 45\% of 1,730 half carcasses evaluated in a packing plant in Goias state, Brazil, had abscesses restricted to the forequarter, specifically in the chuck, shoulder, hump, and neck areas. In addition, lung abscesses were reported in levels between 2 and 3\% in other studies in South Africa (Jaja, Mushonga, Green, \& Muchenje, 2016) and were associated with pneumonia, penetration of lungs by foreign objects, and parasitism (Fekadu, Legesse, \& Tesfaye, 2012). Abscesses were also reported as one of the major reasons for liver condemnation in Sudan, with rates between 6.3 and 8.0\% (Kheder \& Mohamed, 2021).

Other important causes of condemnation that might have an impact on the public health and the economy was also observed at lower rates. Further studies are ongoing to analyze the impact of cysticercosis, tuberculosis, and fasciolosis condemnations in cattle slaughtered under state sanitary inspection in Bahia, Brazil.

\section{Conclusion}

Nephritis, congestion, emphysema, blood aspiration, renal cysts, and abscesses result in condemnation of cattle slaughtered under the state sanitary inspection in Bahia, Brazil, between 2012 and 2017. The results showed that the main causes of condemnation were not necessarily related to zoonotic diseases but were usually local lesions. Condemnation data from the official state sanitary inspection was an important tool for controlling diseases and improving husbandry and handling of cattle, with a focus on animal welfare.

\section{Acknowledgements}

The authors thank the State Inspection Service from the Diretoria de Inspeção de Produtos de Origem Agropecuária (DIPA) of Agência de Defesa Agropecuária da Bahia (ADAB), Brazil for the data.

\section{References}

Agência Estadual de Defesa Agropecuária do Estado da Bahia (2015). ADAB lança programa de vigilância para tuberculose bovina em matadouros e busca erradicar da doença na Bahia, de 01/12/2015. Recuperado de http://www.adab.ba.gov. br/2015/12/1106/ADAB-lanca-programade-vigilancia-para-tuberculose-bovinaem-matadouros-e-busca-erradicar-dadoenca-na-Bahia.html

Almeida, T. J. O., Silva, S. C. G., Torres, M. B. A. M., \& Franque, M. P. (2017). Lesões macroscópicas e causas de condenação de carcaças e vísceras de bovinos 
abatidos na microrregião de Garanhuns, Pernambuco, Brasil. Medicina Veterinária (UFRPE), 11(4), 292-300. doi: 10.26605/ medvet-n4-1959 Recuperado de http: //www.journals.ufrpe.br/index.php/ medicinaveterinaria/article/view/1959.

Assis, D. R., Rezende-Lago, N. C. M., de Marchi, P. G. F., \& D'Amato, C. C. (2011). Perdas diretas ocasionadas por abscessos e hematomas em carcaças de bovinos. Revista Portuguesa de Ciências Veterinárias, 106(577-580), 47-51. Recuperado de http://www.fmv.ulisboa.pt/ spcv/edicao/12_2011/47-51.htm

Azizi, S., Kheirandish, R., \& Rahimi, E. (2014). Comparison of polymerase chain reaction and Warthin-Starry techniques to detect Leptospira spp. in kidneys of slaughtered cattle. Onderstepoort Journal of Veterinary Research, 81(1), e1-e6. doi: 10.4102/ojvr.v81i1.821 Retrieved from https://journals.co.za/doi/abs/10.4102/ ojvr.v81i1.821

Bem Bidone, N., Gonçalves, A. P., Bremm, C. Girotto, A. F., Girotto-Soares, A., Santos, P.,... Soares, J. F. (2021). Slaughter condemnation in bovine due to parasitic lesions and their economic impact in Federal Inspection System establishments in Brazil and in State Inspection System in Rio Grande do Sul state. Brazilian Journal of Veterinary Parasitology, 30(1), e022720. doi: $\quad$ 10.1590/S1984-296120201079 Retrieved from https://www.scielo.br/j/ rbpv/a/qxJXcnrB6cvZHvVKL9fDz9k/?lan $\mathrm{g}=\mathrm{en}$

Bica, R. F. P., Copetti, M. V., \& Brum, M. C. S. (2018). Hydatidosis, cysticercosis, and tuberculosis rates in bovine slaughtered under state sanitary inspection in Bahia, Brazil. Ciência Rural, 48(8), e20170811. doi: $\quad 10.1590 / 0103-8478 c r 20170811$
Retrieved from https://www.scielo.br/j/ cr/a/ptKGGkdQpSj9wbvprHnmwPn/ abstract/?lang=en

Dantas, R. A., Pimentel, M. M. L., Câmara, F. V., Batista, J. S., \& Dias, R. V. C. (2015). Incidência de lesões pulmonares em bovinos destinados ao abate no município de Mossoró, RN. Revista Brasileira de Higiene e Sanidade Animal, 9(3), 411424. doi: 10.5935/1981-2965.20150038 Retrieved from http://www. higieneanimal. ufc.br/seer/index.php/higieneanimal/ article/view/253

Decreto no. 9.013, de 29 de março de 2017. Regulamenta a Lei No. 1.283, de 18 de dezembro de 1950, e a Lei No. 7.889, de 23 de novembro de 1989, que dispõem sobre a inspeção industrial e sanitária de produtos de origem animal. Brasília, DF. Diário Oficial da União, 29 mar. 2017.

Fekadu, A., Legesse, E., \& Tesfaye, D. (2012). The cause, rate and economic implication of organ condemnation of cattle slaughtered at Jimma municipal abattoir, Southwestern Ethiopia. Global Veterinaria, 9(4), 396400. doi: 10.5829/idosi.gv.2012.9.4.6579 Retrieved from https://www.cabdirect. org/cabdirect/abstract/20123396400.

Ferreira, J. S., Neto, Silveira, G. B. da, Rosa, B. M., Gonçalves, V.S. P., Grisi, J. H. H., Fo., Amaku, M.,... Lage, A. P. (2016). Analysis of 15 years of the National program for the control and eradication of animal Brucellosis and Tuberculosis, Brazil. Semina: Ciências Agrárias, 37(5), 3385-3402. doi: 10.5433/1679-0359.2016v37n5Supl2 p3385 Retrieved from: https://www.uel. br/revistas/uel/index.php/semagrarias/ article/view/27292/0

Fruet, A. P. B., Fabrício, E. A., Kirinus, J. K., Scortegagna, A., Dörr, A. C., \& Nörnberg, J. L. (2013). Perdas econômicas oriundas 
das condenações de vísceras bovinas em matadouros de Santa Maria, Rio Grande do Sul. Revista Brasileira de Ciência Veterinária, 20(2), 99-103. doi: 10.4322/ rbcv.2014.053 Retrieved from https:// periodicos.uff.br/rbcv/article/view/6951

Instituto Brasileiro de Geografia e Estatística (2021). Estatística da produção pecuária Brasil. Recuperado de https://sidra.ibge. gov.br

Jaja, I. F., Mushonga, B., Green, E., \& Muchenje, V. (2016). Prevalence of lung lesions in slaughtered cattle in the Eastern Cape Province, South Africa. Journal of the South African Veterinary Association, 87(1), a1362, doi: 10.4102/jsava.v87i1. 1362 Retrieved from http://www.scielo. org.za/scielo.php?script=sci_arttext\&pid =S1019-91282016000100009

Kheder, D., \& Mohamed, A. (2021). A study on causes of cattle liver condemnation at an abattoir in Omdurman area, Khartoum State, Sudan. BMC Veterinary Research, 17, 58. doi: 10.1186/s12917-021-027664 Retrieved from https://bmcvetres. biomedcentral.com/articles/10.1186/ s12917-021-02766-4

Khedri, J., Radfar, M. H., Nikbakht, B., Zahedi, R., Hosseini, M., Azizzadeh, M., \& Borji, H. (2021). Parasitic causes of meat and organs in cattle at four slaughterhouses in Sistan-Baluchestan Province, Southeastern Iran between 2008 and 2016. Veterinary Medicine and Science, 7(4), 1230-1236. doi: 10.1002/vms3.475 Retrieved from https://onlinelibrary.wiley. com/doi/full/10.1002/vms3.475

Lima, L. G. F., Bueno, C. P., Rodrigues, L. M., Gontijo, L. M. A., Ferro, D. A. C., Coelho, K. O.,... Paula, R. S. (2019). Losses caused by carcass bruising in a packing plant in Goiás State. Semina:
Ciências Agrárias, 40(6), 3729-3740. doi: 10.5433/1679-0359.2019v40n6Supl3 p3729 Retrieved from http://www.uel. br/revistas/uel//index.php/semagrarias/ article/view/36039

Marino, P. C., Bonesi, G. L., Negri, L. C., Fo, Furlan, D., Augusto, D. N., Bogado, A. L. G.,... Okano, W. (2016). Lesões pulmonares de bovinos encontradas na inspeção postmortem em matadouros frigoríficos no estado do Paraná. Revista Brasileira de Higiene e Sanidade Animal, 10(4), 669676. doi: 10.5935/1981-2965.20160053 Recuperado de http://www.higieneanimal. ufc.br/seer/index.php/higieneanimal/ article/view/352

Molla, D., Nazir, S., Mohammed, A., \& Tintagu, T. (2020). Parasitic infection as major cause of abattoir condemnations in cattle slaughtered at an Ethiopian abattoir: 10-years retrospective study. Journal of Helminthology, 94, e31, 1-7. doi: 10.1017/ S0022149X1900004X Retrieved from https://www.cambridge.org/core/journals/ journal-of-helminthology/article/abs/ parasitic-infections-as-major-causeof-abattoir-condemnations-in-cattleslaughtered-at-an-ethiopian-abattoir10year-retrospective-study/53A97DBE637DF85D302F8F2CDDE59C5C

Mummed, Y. Y., \& Webb, E. C. (2015). Causes of beef carcass and organ condemnations in Ethiopia. Asian Journal of Animal and Veterinary Advances, 10(4), 147-160. doi: 10.3923/ajava.2015.147.160 Retrieved from https://scialert.net/fulltext/?doi=ajav a.2015.147.160\&org=10

Oliveira, L. L. S., Silva, F. V., Alves, C. A., Batista, L. F., Soares, F. D. S., Rocha, V. R., Jr.,... Alves, D. D. (2020). Prevalence and geographical distribution of bovine cysticercosis in the mesoregion of Northern Minas Gerais. 
Revista Brasileira de Saúde e Produção Animal, 21, e2121172020. doi: 10.1590/ s1519-99402121172020 Retrieved from https://www.scielo.br/j/rbspa/a/ TtDFp6VtqnznJ3dZXMcCyKv/ abstract/ ?lang=en

Silva, V. L., Groff, A. M., Bassani, C. A., \& Pianho, C. R. (2016). Causas de condenação total de carcaças bovinas em um frigorífico do estado do Paraná. Relato de Caso. Revista Brasileira de Higiene e Sanidade Animal,
10(4), 730-741. doi: 10.5935/1981-2965. 20160060 Recuperado de http://www. higieneanimal.ufc.br/seer/index.php/ higieneanimal/article/view/365

Sistema de Informações Gerenciais do Serviço de Inspeção Federal (2021). Consulta de dados do SIGSIF. Recuperado de https://sigsif.agricultura.gov.br/sigsif_ cons/\%21sigsif.ap_condenacao_ especie_rep_cons 
